University of Nebraska - Lincoln

DigitalCommons@University of Nebraska - Lincoln

Publications, Agencies and Staff of the U.S.

Department of Commerce

U.S. Department of Commerce

2007

\title{
Antler Size of Alaskan Moose Alces alces gigas: Effects of Population Density, Hunter Harvest and Use of Guides
}

Jennifer I. Schmidt

Institute of Arctic Biology, University of Alaska Fairbanks, Fairbanks

Jay M. Ver Hoef

National MarineMammal Laboratory, National Oceanic and Atmospheric Association, U.S. Department of Commerce

R. Terry Bowyer

Idaho State University, Pocatello

Follow this and additional works at: https://digitalcommons.unl.edu/usdeptcommercepub

Part of the Environmental Sciences Commons

Schmidt, Jennifer I.; Ver Hoef, Jay M.; and Bowyer, R. Terry, "Antler Size of Alaskan Moose Alces alces gigas: Effects of Population Density, Hunter Harvest and Use of Guides" (2007). Publications, Agencies and Staff of the U.S. Department of Commerce. 179.

https://digitalcommons.unl.edu/usdeptcommercepub/179

This Article is brought to you for free and open access by the U.S. Department of Commerce at DigitalCommons@University of Nebraska - Lincoln. It has been accepted for inclusion in Publications, Agencies and Staff of the U.S. Department of Commerce by an authorized administrator of DigitalCommons@University of Nebraska - Lincoln. 


\title{
Antler size of Alaskan moose Alces alces gigas: effects of population density, hunter harvest and use of guides
}

\author{
Jennifer I. Schmidt, Jay M. Ver Hoef \& R. Terry Bowyer
}

Schmidt, J.I., Ver Hoef, J.M. \& Bowyer, T. 2007: Antler size of Alaskan moose Alces alces gigas: effects of population density, hunter harvest and use of guides. - Wildl. Biol. 13: 53-65.

Moose Alces alces gigas in Alaska, USA, exhibit extreme sexual dimorphism, with adult males possessing large, elaborate antlers. Antler size and conformation are influenced by age, nutrition and genetics, and these bony structures serve to establish social rank and affect mating success. Population density, combined with anthropogenic effects such as harvest, is thought to influence antler size. Antler size increased as densities of moose decreased, ostensibly a density-dependent response related to enhanced nutrition at low densities. The vegetation type where moose were harvested also affected antler size, with the largest-antlered males occupying more open habitats. Hunts with guides occurred in areas with low moose density, minimized hunter interference and increased rates of success. Such hunts harvested moose with larger antler spreads than did nonguided hunts. Knowledge and abilities allowed guides to satisfy demands of trophy hunters, who are an integral part of the Alaskan economy. Heavy harvest by humans was also associated with decreased antler size of moose, probably via a downward shift in the age structure of the population resulting in younger males with smaller antlers. Nevertheless, density-dependence was more influential than effects of harvest on age structure in determining antler size of male moose. Indeed, antlers are likely under strong sexual selection, but we demonstrate that resource availability influenced the distribution of these sexually selected characters across the landscape. We argue that understanding population density in relation to carrying capacity $(\mathrm{K})$ and the age structure of males is necessary to interpret potential consequences of harvest on the genetics of moose and other large herbivores. Our results provide researchers and managers with a better understanding of variables that affect the physical condition, antler size, and perhaps the genetic composition of populations, which may be useful in managing and modelling moose populations.

Key words: Alaska, antler size, density dependence, harvest, guides, moose

Jennifer I. Schmidt, Institute of Arctic Biology, University of Alaska Fairbanks, Fairbanks, AK 99775,USA - e-mail: fsjis@uaf.edu

Jay M. Ver Hoef, National Marine Mammal Laboratory, National Oceanic and Atmospheric Association, U.S. Department of Commerce, 6700 Sand Point Way NE, Seattle,WA, 98115, USA - e-mail: jay.verhoef@noaa.gov R. Terry Bowyer, Department of Biological Sciences, Idaho State University, Pocatello, ID 83209, USA - e-mail: bowyterr@isu.edu

Corresponding author: R. Terry Bowyer

Received 30 June 2005, accepted 10 January 2006

Associate Editor: Bernt-Erik Sather

() WILDLIFE BIOLOGY $\cdot 13: 1$ (2007)

This article is a U.S. government work, and is not subject to copyright in the United States. 
Growth, size and conformation of antlers among cervids are dependent upon a combination of age, nutrition and genetics (Gross 1983, Hartl et al. 1995, Asleson et al. 1996, 1997). Antler growth and size are directly influenced by forage availability and the ability of cervids to garner foods of high nutritional value (French et al. 1965, Brown 1990, Strickland \& Demarais 2000). Population density relative to carrying capacity $(\mathrm{K})$ is important in determining amount and quality of food obtained by individuals (McCullough 1979, Schmidt et al. 2001, Kie et al. 2003, Festa-Bianchet et al. 2004, Stewart et al. 2005). We define $K$ as the number of animals at or near a long-term equilibrium with their food supply (Kie et al. 2003). Nutrients sequestered by male cervids must be allocated first for basic metabolic needs, including growth (Barboza \& Bowyer 2000). Indeed, only when these metabolic requirements for growth are met, resources can be fully invested in antler growth by males (French et al. 1965, Bowyer 1986, Stewart et al. 2000). Moreover, increased intraspecific competition for resources occurs in ungulate populations at high densities relative to $\mathrm{K}$, which diverts energy away from development of secondary sexual characteristics such as antlers (McCullough 1979, Ferguson et al. 2000, Schmidt et al. 2001, Stewart et al. 2000). Moose Alces alces invest substantial energy and resources in antler development (Stewart et al. 2000, Bowyer et al. 2001b), which can be limited by forage and nutrient availability in relation to $\mathrm{K}$ (Moen \& Pastor 1998, Bowyer et al. 2002a).

Another critical component determining antler morphology in cervids is age (Clutton-Brock 1982, McCullough 1982, Miquelle 1990, Stewart et al. 2000, Bowyer et al. 2001b, Yoccoz et al. 2002, Mysterud et al. 2003). The relationship between age and the size and conformation of antlers is especially well documented for Alaskan moose $A$. a. gigas (Bowyer et al. 2001b). Animals invest differentially based on age, with prime, larger males that have reached asymptotic body growth allocating more resources towards antler growth, symmetry and size than smaller males (Stewart et al. 2000, Bowyer et al. 2001b, Yoccoz et al. 2002). In Alaskan moose, males do not attain full body growth until about eight years old (Spaeth et al. 2001). In polygynous mating systems typical of sexually dimorphic cervids (Geist 1966, Ralls 1977, Weckerly 1998, Loison et al. 1999), dominant males often limit mating opportunities of younger, smaller males (Hirth 1977, Bowyer 1986, Van Ballenberghe \& Miquelle
1996). In the absence of old, large males, the age at which males mate decreases (McCullough 1982, Strickland et al. 2001, Jenks et al. 2002, Singer \& Zeigenfuss 2002). An earlier age of mating may result in younger males making large investments in antler development and size (Mysterud et al. 2003). Moreover, age structure is influenced by population density relative to $\mathrm{K}$ and human harvest; populations held away from $\mathrm{K}$ by heavy harvest have young age-class distributions ( $\mathrm{McCul}$ lough 1982, Bowyer et al. 1999, Sæther et al. 2001). Trophy harvest of young bighorn sheep Ovis canadensis has also been instrumental in increasing mating success of young animals (Coltman et al. 2002).

Moose provide an excellent opportunity for understanding effects of harvest on antler characteristics. Much is known about moose antlers, including aspects of their physiology (Sæther \& Haagenrud 1983, Van Ballenberghe 1983, Bubenik 1998, Moen \& Pastor 1998), age-related effects on growth (Stewart et al. 2000), size and conformation (Solberg \& Sæther 1993, 1994, Bowyer et al. 2001b), geographic variation (Sæther \& Haagenrud 1985, Gasaway et al. 1987, Sand et al. 1995, Bowyer et al. 2002a), effects of management strategies (Stewart 1985, Hundertmark et al. 1998, Solberg et al. 1999, Laurian et al. 2000, Fulton \& Hundertmark 2004), age structure (Solberg et al. 1999, Bowyer et al. 2001b, Sæther et al. 2001) and characteristics of those hunting them (Sæther et al. 2003, Schmidt et al. 2005). Moreover, antler size and complexity in males is positively related to sperm production and quality (Malo et al. 2005). Yet, almost nothing is known about how population density, intensity of harvest and motivation of hunters interact to affect the size of harvested moose. Indeed, debate continues over whether maximal harvest and trophy management are compatible management strategies (Jenks et al. 2002).

Moose populations in interior Alaska occur at low densities because of predation (Gasaway et al. 1992, Bowyer et al. 1998); hence, nutrition would tend not to limit antler growth, except for areas south of Fairbanks, Alaska, USA, where densitydependent responses have occurred (Keech et al. 2000). Moreover, Bender et al. (2003) and FestaBianchet et al. (2004) demonstrated that phenotypic responses can be measured when nutritional conditions do not limit potential growth.

Hunters often base harvest decisions on horn or antler size, and wildlife managers have used size

(c) WILDLIFE BIOLOGY · 13:1 (2007) 
restrictions on horns and antlers to limit harvest, which in turn may affect the size of the horn-like structures and the demographics of ungulate populations (McCullough 1979, Thelen 1991, Schwartz et al. 1992, Strickland et al. 2001, Festa-Bianchet et al. 2004). Understanding such complex interactions, including density-dependent responses, as well as influences of harvest on age structure of populations, is essential for the conservation and sound management of these large herbivores.

The motivation and satisfaction that individuals obtain from hunting are diverse, including those derived from subsistence, recreation, mentoring, economics and trophy harvest (Hendee 1974, Ericsson et al. 2000, Heberlein \& Kuentzel 2002, Frey et al. 2003). Sport hunting contributes significantly to the Alaskan economy providing both employment and revenue (Snepenger \& Bowyer 1990, Albert et al. 2001). In particular, employment of a guide can be financially costly and is not required by law for moose hunting in Alaska; therefore, hunters typically expect guides to satisfy their goals. Hunters often select males with large horn-like structures (Stewart 1985, Hartl et al. 2003, Festa-Bianchet et al. 2004). In addition, analyses of hunter-harvest tickets indicate that most clients of guides are non-residents, who invest substantially to harvest moose in Alaska (Schmidt et al. 2005). Guides would be expected to try to satisfy their clients by providing an opportunity to harvest a moose with large antlers.

The foregoing arguments lead us to offer the following hypotheses concerning the harvest of moose in relation to the size of their antlers: 1) we predict that antler size will exhibit a negative relationship with moose population density, because areas with low density will be on a higher nutritional plane and, in consequence, moose will have larger antlers at low than at high densities with respect to $\mathrm{K}$; 2) we also hypothesize that habitats in which moose are harvested would relate to the size of their antlers; 3) moreover, experience and skill should result in guides selectively hunting in areas with low moose density compared with non-guided hunts; 4) we also predict that, regardless of population densities, guided hunts will continue to selectively harvest moose with larger antlers than nonguided harvest within the same stratum of moose density; 5) in addition, guides will choose areas with lower hunter-to-moose ratios, thereby demonstrating skill and selectivity in attempting to satisfy the preference of clients for moose with large antlers; 6)

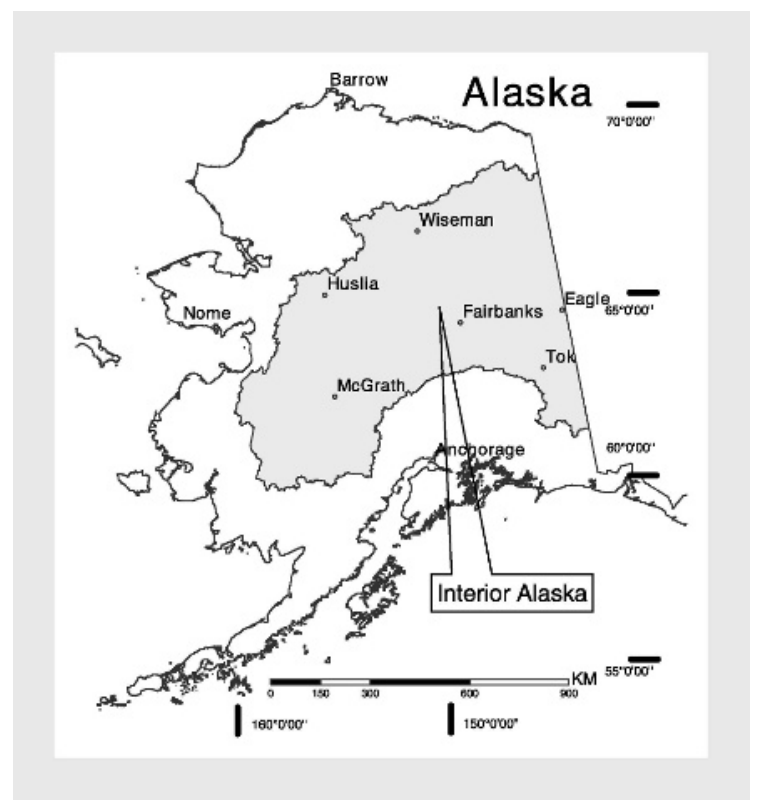

Figure 1. Location of the study area where moose were harvested in interior Alaska, USA.

finally, we posit that heavily harvested areas, independent of density, will yield moose with smaller antlers, because harvest will reduce the age structure of males in those areas.

\section{Material and methods}

\section{Locality and data}

The Alaska Range (1,000-6,000 $\mathrm{m}$ a.s.1.) to the south and the Brooks Range (1,000-2,500 m a.s.1.) to the north (Fig. 1) border our study area, which encompasses most of interior Alaska $\left(569,694 \mathrm{~km}^{2}\right)$. Snow typically remains loose and dry with an average depth of usually $<70 \mathrm{~cm}$ (Gasaway et al. 1983, Keech et al. 2000, Yarie \& Billings 2002); annual precipitation is $24 \mathrm{~cm}$ (O'Neill et al. 2002) and temperatures range within $+14^{\circ} \mathrm{C}--30^{\circ} \mathrm{C}$ (Fleming et al. 2000). Schmidt et al. (2005) provide a comprehensive description of the study area.

Data were obtained from files kept by the Alaska Department of Fish and Game (ADF\&G), and are based on harvest tickets collected from all moose hunters regardless of their success. Other researchers have used harvest tickets as they hypothesise that they accurately reflect hunting activity in Alaska (Albert et al. 2001). We examined results of guided versus non-guided moose hunts and use of transporters (i.e. outfitters) within interior Alaska between 1997 and 2001. Guides in our analysis are 
registered in the State of Alaska, and transporters are any person paid to provide transportation during a moose hunt. Uniform coding units (UCUs) were the basis for our spatial sampling units, because UCUs are the location reported on hunter harvest tags (UCUs, $\mathrm{N}=217, \overline{\mathrm{x}}=1,028 \mathrm{~km}^{2}, \mathrm{SE}=$ $5.6 \mathrm{~km}^{2}$ ). UCUs typically are defined by landscape features such as ridge tops and rivers, and several units often occur within the larger Game Management Units (GMUs). Management usually occurs at the level of the GMU, which defined the spatial extent of our study. To minimize spatial differences, such as access or use of private landing strips between guided and non-guided hunts, we restricted our analysis to only UCUs in which guiding occurred. Therefore non-guided hunts occurred in the same areas as those used by guides. Maps for UCUs were provided by the Division of Wildlife Conservation of ADF\&G.

Aerial surveys, conducted by $\mathrm{ADF} \& \mathrm{G}$ during autumn 1997-2001, were used to estimate densities of moose in interior Alaska. Survey methods involved counting moose in randomly selected sample units of 2' latitude and 5' longitude within survey areas from small fixed-winged aircraft (Ver Hoef 2001, 2002). We surveyed $39,332 \mathrm{~km}^{2}$; some units were sampled in multiple years, resulting in a total of 2,665 units used in the analyses. Surveys were conducted when snow cover and daylight were adequate, which often was only possible after the hunting season. We selected only females for analysis of density because they exhibit more site fidelity than males (Ballard et al. 1991), and reflect the spatial distribution of both sexes during autumn when the sexes are aggregated (Miquelle et al. 1992). Sampling later in winter might have provided biased results because the sexes of moose spatially segregate following the mating season (Miquelle et al. 1992, Bowyer et al. 2001a, Bowyer 2004). Also, females were used because the hunting season occurred immediately prior to surveys and 'male only' harvest are common in interior Alaska (Schwartz et al. 1992, Hundertmark et al. 1998). Consequently, estimates for females are less biased by changes in density from hunting than would be estimates that included males. Schmidt et al. (2005) provide a more detailed description of sampling protocols.

Moose densities (females $/ \mathrm{km}^{2}$ ) within UCUs $(\mathrm{N}=599)$ were divided into three categories based on 'smart quantiles' which look for natural breaks in data (Johnston et al. 2001). We used categories for two main reasons. First, they are useful for data in which a large portion of samples falls within a small range, but may have valid extreme values (Johnston et al. 2001). These extreme values can have undue leverage for continuous models (Rousseeuw \& Van Zomeren 1990). Second, categories can reveal nonlinear relationships. Our categorization resulted in high ( $\overline{\mathrm{x}}>0.41$ females $\left./ \mathrm{km}^{2} ; \mathrm{N}=425\right)$, medium $\left(0.21<\overline{\mathrm{x}}<0.41\right.$ females $\left./ \mathrm{km}^{2} ; \mathrm{N}=120\right)$ and low $\left(\overline{\mathrm{x}}<0.21\right.$ females $\left./ \mathrm{km}^{2} ; \mathrm{N}=54\right)$ groupings of moose density, which likely correspond to populations subjected to various levels of predation by large carnivores (sensu Gasaway et al. 1992). Even though low density of moose does not necessarily indicate the position of a population in relation to K (Kie et al. 2003), Gasaway et al. (1992) argued convincingly that moose populations in interior Alaska were typically held below $\mathrm{K}$ by predation. Areas south of Fairbanks, however, have increased in density recently and measures of physical condition and reproduction indicate that those populations may be approaching K (Keech et al. 2000). These high-density areas provide a benchmark by which to judge other population densities of moose inhabiting the boreal forest.

Mean antler spread (in $\mathrm{cm}$ ) was calculated across the previously defined categories of moose density $\left(\right.$ females $\left./ \mathrm{km}^{2}\right)$. Antler spread is a reliable index of the overall size of moose antlers (Gasaway et al. 1987, Stewart et al. 2000, Bowyer et al. 2001b). Moreover, antler spread correlates well with Boone $\&$ Crockett's scores used to assess trophy antlers in moose (Gasaway et al. 1987).

\section{Statistical analyses}

We controlled for effects of access between guided and non-guided hunts by subsetting data for those analyses to contain only hunts that used airplanes for transportation. We used analysis of variance (ANOVA) to explore the relationship of antler size of harvested moose (dependent variable) at low, medium and high densities, and whether a guide was employed (main effects; Zar 1999). In addition, we simultaneously modelled effects of moose density, guide use and their interaction with antler size (dependent variable). Because harvest can change age structure with possible effects on antler size independent of moose density (i.e. mostly males are harvested), we also modelled antler size with harvest intensity per moose density class as a covariate (ANCOVA) and categories of moose density as the main effect. A posteriori tests were conducted to further explore pairwise differences in moose den- 
Table 1. Proportion of guided, non-guided, transported and non-transported hunts and antler size (in $\mathrm{cm}$ ), as measured by spread, occurring in areas with low, medium and high densities of moose during 1997-2001 in interior Alaska, USA. Different sample sizes occur between hunting characteristics and antler spread because of differential reporting on harvest tickets. The P-values indicate significant differences in mean antler size between moose densities.

\begin{tabular}{|c|c|c|c|c|c|c|c|c|}
\hline $\begin{array}{l}\text { Moose density } \\
\left(\text { females } / \mathrm{km}^{2}\right)\end{array}$ & $\begin{array}{c}\text { Guided } \\
(\mathrm{N}=1459)\end{array}$ & $\begin{array}{c}\text { Non-guided } \\
(\mathrm{N}=4647)\end{array}$ & $\begin{array}{l}\text { Transported } \\
(\mathrm{N}=2638)\end{array}$ & $\begin{array}{c}\text { Non-transported } \\
(\mathrm{N}=3468)\end{array}$ & $\mathrm{X}$ & SD & $\mathrm{N}$ & P-value \\
\hline Low $(\mathrm{X}<0.21)$ & 0.89 & 0.64 & 0.67 & 0.72 & 113.55 & 0.38 & 7933 & $<0.0001$ \\
\hline Medium $(0.21<\mathrm{X}<0.406)$ & 0.07 & 0.14 & 0.16 & 0.10 & 106.21 & 0.37 & 4095 & $<0.0001$ \\
\hline $\operatorname{High}(X>0.406)$ & 0.03 & 0.22 & 0.17 & 0.18 & 100.57 & 0.38 & 4009 & $<0.0001$ \\
\hline
\end{tabular}

sity for guided and non-guided hunts. Although we do not know the age of harvested moose, this analysis helps control for age differences resulting from intensity of harvest. We used ANOVA with hunter intensity (dependent variable) and moose density (main effect) to predict size of antlers; harvest intensity was defined as the number of moose taken divided by their population density. All analysis used the GLM procedure in SAS (SAS Institute Inc. 1999).

To further explore effects of habitat on antler size of moose, we used linear regression (SAS Proc REG) to predict size of antlers based on relative proportion of vegetation type present within the UCU where harvest occurred. Vegetation types were low shrubs $(<200 \mathrm{~cm}$ tall), deciduous trees and shrubs, which included willow Salix spp., birch Betula spp., aspen Populus tremuloides, balsom poplar Populus balsamifera, white and black spruce Picea glauca and P. marina, and ice or rock. We also assessed aspect which was transformed to its sine and cosine (Zar 1999).

We used ANOVA to test for effects of hunter-tomoose ratio (dependent variable), with main effects of moose density (low, medium, high), use of guides and their interaction (Zar 1999). Similar to antler size, pairwise differences between hunter-to-moose ratios were performed to examine differences in moose densities. An index of hunter interference was calculated based on the ratio of hunter density to moose density (Schmidt et al. 2005). Because estimates of moose density are 5-year means, estimates of hunter density were also averaged across the same five years. Fortunately, the number of moose hunters in interior Alaska remained relatively constant during 1997-2001, ranging from 1,781 to 1,865 reported hunters. Hunter presence in the UCUs was calculated by totalling the number of hunters in a UCU, regardless of success, from 1997 to 2001. Five-year estimates of hunter presence for each UCU were then divided by 5-year estimates of moose density. An arcsine transforma- tion was needed to normalize the hunter-to-moose ratio (Zar 1999), although untransformed means are presented for descriptive purposes. Statistical analyses were performed using SAS/STAT software (SAS Institute 1999).

\section{Results}

\section{Moose density, habitat and use of guides}

Moose density (females $/ \mathrm{km}^{2}$ ) influenced antler size of harvested moose, with a continual increase $(\mathrm{P}<$ 0.0001 ) in size (spread) from areas with high to low densities (Table 1). Furthermore, ANOVA with harvest as a covariate still resulted in significant differences in antler size between areas with low $\left(\overline{\mathrm{x}}_{\mathrm{adj}}=127.6, \mathrm{SD}=0.71 \mathrm{~cm}\right)$, medium $\left(\overline{\mathrm{x}}_{\mathrm{adj}}=\right.$ $117.9, \mathrm{SD}=1.52 \mathrm{~cm})$ and high $\left(\overline{\mathrm{x}}_{\mathrm{adj}}=100.1, \mathrm{SD}=\right.$ $1.17 \mathrm{~cm})$ density $(\mathrm{P}<0.0001, \mathrm{~N}=27,308)$. The relative proportion of vegetation types in UCUs where moose were harvested affected size of antlers: low shrub $(\mathrm{F}=4.28)$, deciduous $(\mathrm{F}=3.65)$, ice and rock $(\mathrm{F}=3.60)$, and spruce $(\mathrm{F}=3.19)$.

Guided hunts also resulted in harvest of males with larger antlers $(\overline{\mathrm{x}}=147.4, \mathrm{SD}=17.5 \mathrm{~cm})$ compared with non-guided hunts $(\overline{\mathrm{x}}=121.0, \mathrm{SD}=$ $31.9 \mathrm{~cm} ; \mathrm{N}=2,755$; $\mathrm{P}<0.0001)$. Interaction between moose density and guiding, however, was marginally not significant $(\mathrm{F}=2.22, \mathrm{P}=0.11)$. Furthermore, the strength of the relationship explained by guiding $(\mathrm{F}=346.34)$ was substantially greater than for moose density $(\mathrm{F}=92.63$; $\mathrm{P}<$ $0.0001 ; \mathrm{N}=2,755)$. This outcome indicates that even though guiding is the dominant effect on the size of antlers of harvested moose, density of moose still plays a role in affecting size of antlers. Furthermore, when analyses were not restricted to only UCUs where guiding occurred, the strength of the relationship explained by moose density $(\mathrm{F}=$ 448.83) became substantially greater than guiding $(\mathrm{F}=37.25)$ in the same model $(\mathrm{P}<0.0001 ; \mathrm{N}=$ $3,327)$. A large proportion of guided hunts $(89.2 \%$; 
$\mathrm{N}=1,301)$ occurred in areas with low density compared with non-guided hunts $(63.8 \% ; \mathrm{N}=2,966)$. If a hunter employed a guide, they were 26 times more likely to hunt in areas with low than with high moose density. Non-guided hunts in areas with low moose density made up the largest proportion of hunts; however, hunts in low-density areas were only three times more common than hunts in areas with high density. Consequently, we expected overall antler size of harvested males to be larger in guided hunts because moose in low-density areas possess larger antlers, and those areas made up a larger proportion of guided than of non-guided hunts. Indeed, all pairwise differences regarding antler size were significant $(\mathrm{P}<0.035$; Fig. 2$)$. Non-guided hunts also tended to occur in areas with low moose densities (see Table 1); however, the proportion of non-guided hunts in locations of medium and high density did not decrease as sharply as with use of guides (see Table 1).

\section{Selectivity and intensity of harvest}

Hunters that employed transporters did not exhibit the same selectivity for areas with low density of potentially larger-antlered males (see Table 1).

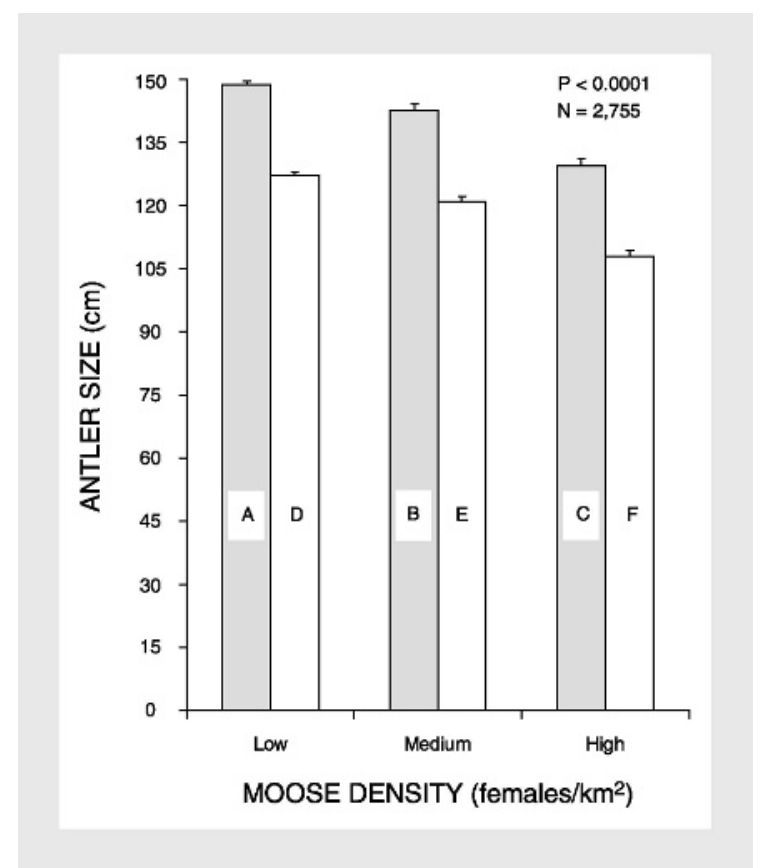

Figure 2. Mean antler size (in $\mathrm{cm} \pm \mathrm{SD}$ ) of moose harvested by guided $(\square)$ and non-guided $(\square)$ hunts during 1997-2001 in interior Alaska, USA. Whenever a bar has a different letter from any other bar it is significantly different $(\mathrm{P}<0.05, \mathrm{df}=5)$. The $\mathrm{P}$ value on the figure represents the overall significance of comparisons of mean antler sizes.
Far less difference in antler size of harvested moose occurred among density categories for hunts with and without the use of a transporter than for guided and non-guided hunts (see Table 1). Only a 4-fold increase occurred in use of low versus high-density areas by hunters who employed a transporter, compared with the 26-fold increase with use of a guide.

We also tested whether guides sought out areas that were less frequently visited by other hunters relative to moose density. Indeed, the hunter-tomoose ratio was lower in areas used by guides in all three categories of moose densities $(\mathrm{P}<0.0001$; Fig. 3). Unlike antler size, however, the interaction term for hunter-to-moose ratio was significant $(\mathrm{P}<$ 0.0001). Further analyses revealed that among guided hunts, locations with medium densities of moose had a hunter-to-moose ratio that was near equal to that of hunts in areas with high moose density (see Fig. 3); all pairwise comparisons were significant $(\mathrm{P}<0.05)$.

Intensity of hunter harvest and moose density significantly influenced antler size of moose $(\mathrm{P}<$ 0.0001; Fig. 4). Antler size decreased as harvest intensity increased within medium and high-density populations; however, within areas of low density, a heavy harvest resulted in larger antlers than from medium-density areas, but less than from lightly harvested areas (see Fig. 4). Antler size decreased from high-density areas to areas of low density (see Fig. 4).

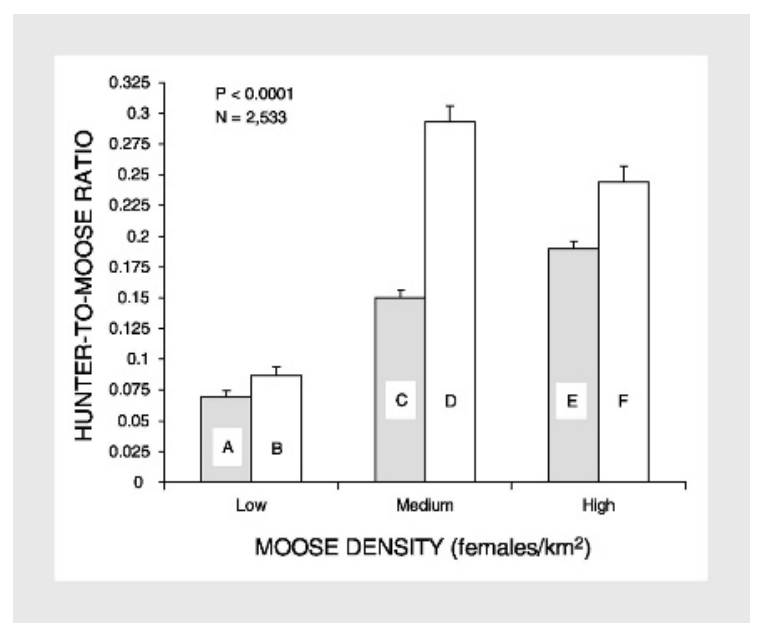

Figure 3. Hunter-to-moose ratio in areas used by guided ( $\square$ ) and non-guided $(\square)$ hunters during 1997-2001 in interior Alaska, USA. Whenever a bar has a different letter from any other bar it is significantly different $(\mathrm{P}<0.05, \mathrm{df}=5)$. The $\mathrm{P}$-value on the figure represents the overall significance of comparisons of hunter-to-moose ratios. 


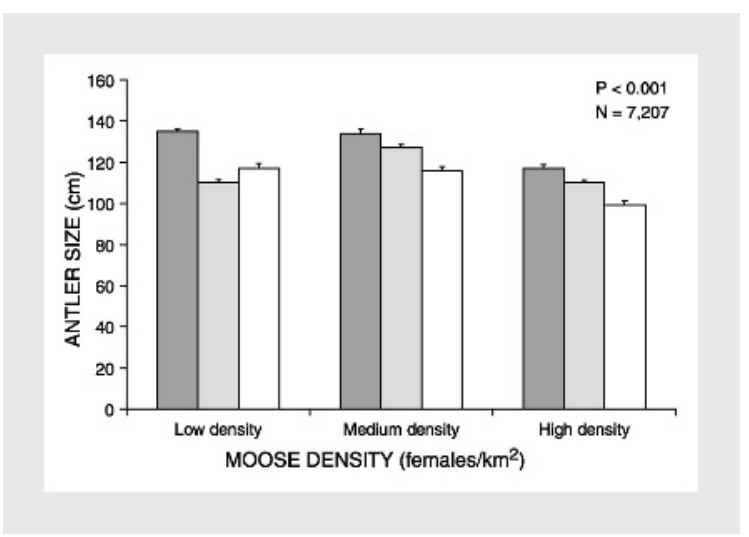

Figure 4. Mean antler size (in $\mathrm{cm} \pm \mathrm{SD}$ ) of moose by harvest intensity (( $\square)$ light harvest, $(\square)$ medium harvest and $(\square)$ heavy harvest) across moose density during 1997-2001 in interior Alaska, USA.

\section{Discussion}

\section{Antler size and population density}

We accepted our hypothesis that moose density would be negatively related to antler size in Alaskan moose. Gasaway et al. (1987) demonstrated that site-specific variation in size of moose antlers occurred across Alaska; though, the cause for such a variation was unknown. Bowyer et al. (2002a) attributed variation in antler size to the habitats occupied by harvested moose, but could not rule out genetic differences in some instances.

Moose in Alaska typically are held at low densities by predation rather than by hunter harvest (Gasaway et al. 1992); hunting by carnivores and humans may cause substantial differences in the demographics of large mammals (Berger 2005). Hunts in Alaska are mostly 'male only' (Schwartz et al. 1992, Hundertmark et al. 1998), and influences on population size and productivity are thus minimal. Many areas are difficult for hunters to access, thereby limiting harvest for much of the interior Alaska (Schmidt et al. 2005). Moreover, Alaskan moose have a highly polygynous mating system with female density primarily regulating population dynamics under such circumstances (McCullough 1979, Bowyer et al. 1999, Kie et al. 2003). Indeed, Alaskan moose mate in harems, which differ markedly from the mating system of other subspecies of moose (Molvar \& Bowyer 1994, Bowyer et al. 2003); management objectives for other subspecies often reflect the need for a higher proportion of males in the population to ensure mating synchrony
(Crête et al. 1981, Timmermann et al. 1998, Whittle et al. 2000). Males can play a role in the population demography of moose, especially at low density or where their age structure is very young (Mysterud et al. 2002, Sæther et al. 2003, 2004). Even the heaviest harvest of moose in Alaska (Bowyer et al. 1999), however, seldom reach levels reported for Fennoscandia (Sæther et al. 2003, 2004).

Males and females of polygynous ruminants sexually segregate for much of the year (Bowyer 1984, Miquelle et al. 1992, Bleich et al. 1997, Kie \& Bowyer 1999, Bowyer et al. 2001a, 2002b, Bowyer 2004). Nevertheless, density-dependent effects on the physical condition of females can limit growth of horns and antlers in males (Clutton-Brock et al. 1997, Jorgenson et al. 1998, McCullough 2001). Young Alaskan moose may have difficulty in compensating for low birth weights (Schwartz et al. 1994, Keech et al. 1999), as do some other cervids (Schultz \& Johnson 1995, Pélabon 1997). Indeed, harvested moose from low-density areas had larger antlers than those occurring in areas with higher densities (see Table 1, Figs. 2 and 4). Effects of population density on antler size were maintained even when harvest was included as a covariate. Because predation is the dominant regulating mechanism for moose in much of interior Alaska (Gasaway et al. 1992), we hypothesize that antler size of males in low-density populations are positively influenced by their enhanced physical condition. Moreover, antlers are ostensibly under strong sexual selection (Bowyer et al. 2001b), yet we demonstrated that resource availability strongly influenced the distribution of this sexually selected characteristic across the landscape.

\section{Effects of habitat}

We accept our hypothesis that habitat would affect the antler size of harvested moose. Indeed, that outcome offers further evidence for a nutritional basis for differences in antler size in interior Alaska. Furthermore, the strongest effects occurred in low shrub, which were areas preferred by moose because they often contained willows Salix spp. and other palatable shrubs (Molvar et al. 1993, Weixelman et al. 1998, Bowyer et al. 2003). Indeed, moose inhabiting tundra areas tend to have larger antlers than those from areas dominated by boreal forest (Bowyer et al. 2002a), which likely explains the positive influence of more open habitat types on the size of moose antlers. Indeed, moose density is, in part, a function of the habitats they inhabit in in- 
terior Alaska (Maier et al. 2005). Further support for larger antlers in more open environments was illustrated by males occurring in and adjacent to open areas with ice and rocks having larger antlers than those harvested in dense stands of black spruce common in interior Alaska. We hypothesize that this outcome integrates nutritional quality of habitats and density-dependent effects, which allow the phenotypic expression of large antlers.

\section{Selectivity of harvest}

We accepted our hypothesis that guides would hunt in areas with lower moose density, resulting in the harvest of large-antlered males (see Table 1). Further, we accepted our hypothesis that guides would harvest large-antlered males across a range of population densities in interior Alaska (see Fig. 2). We also accepted our hypothesis that guides would hunt in areas with a low hunter-to-moose ratio. These outcomes indicate a high level of hunting skill by guides.

Antler size is often a motivation for sport hunters, and use of guides is common (Stewart 1985, Coltman et al. 2003, Hartl et al. 2003). Accordingly, for guides to be successful, they need to hunt in areas producing large-antlered moose. Indeed, most hunters employing a guide hunted in landscapes with low densities of moose; guides concentrated their hunts in areas with low moose density, which was 26-fold greater than guided hunts in high-density areas (see Table 1). There was a lower use of low-density sites by transporters (four times more than for high-density areas). Regardless of mode of transportation or whether a hunter could afford to hire a transporter to attain access to a desired area, guides exhibited selectivity for low-density areas (see Table 1). Guides clearly possessed some skills other than greater means of access or geographic familiarity with areas where they hunted.

Most moose hunters employing guides were nonresidents who invested substantially in their hunts (e.g. travel to Alaska, employment of a guide and time off work; Schmidt et al. 2005). Therefore, the goals of those individuals may be similar to trophy hunters' who commonly select animals to harvest based on antler size (Stewart 1985, Snepenger \& Bowyer 1990, Hartl et al. 2003). Because larger-antlered moose occur in areas with low density (see Table 1), guides would be expected to satisfy the aspirations of their clients by hunting in such areas.

As a corollary to our prediction that guided hunts would occur more often in areas with low density of moose, we also proposed that guides would harvest moose with larger antlers across all population densities compared with non-guided hunts (see Fig. 2), even when both guided and non-guided hunts used aircraft for transportation. Guided hunts occurred more often in areas with low moose density, and hunters harvested larger males within all density categories of moose (see Fig. 2), indicating additional skill by guides. In addition, previous models of harvest have predicted decreased hunter success with smaller moose-to-hunter ratios (Cooper et al. 2002, Schmidt et al. 2005), resulting in skilled hunters or guides seeking areas with higher ratios. Our results support that finding as well as our prediction that guides would avoid other hunters while maximizing the likelihood of an encounter with a moose (see Fig. 3).

\section{Harvest intensity and antler size}

We observed a general pattern of decreasing antler size from areas with the heaviest harvest of moose. Contrary to our hypothesis, however, antler size did not uniformly decrease as harvest intensity increased. Instead, at low densities, medium harvest intensity resulted in smaller antler size and ostensibly younger age structure than for moose in heavily harvested areas (see Fig. 4).

An inverse relationship is expected between intensity of harvest and age structure; populations with heavy harvest exhibit a downward shift in age structure (McCullough 1979, Bowyer et al. 1999, Jenks et al.2002). Size of antlers has been used as index to age moose with larger antlers implying the oldest moose, although some senescence occurs in old age classes (Gasaway et al. 1987 Stewart et al. 2000, Bowyer et al. 2001b). As harvest intensity increases, size of antlers should decrease because of a concomitantly younger age structure. Moose experienced reductions in age structure resulting from frequent removal of larger and older males via hunting (Solberg et al. 1999, 2000), leaving mostly younger and smaller-bodied males available for harvest. We demonstrated that successful hunters, in areas experiencing heavy harvest and high density of moose, killed males with the smallest antlers. In areas with light harvest of moose, antlers were largest in low-density areas and smallest in highdensity areas (see Fig. 4). We hypothesize that this outcome occurred because of both density-dependent effects of physical condition and a reduced age structure among males. 


\section{Genetics and harvest}

Modelling efforts have predicted probable influences of hunting on antlers of Alaskan moose (Hundertmark et al. 1998). Controversy exists, however, on whether sport hunting influences the genetics of ungulate populations via possible consequences of selective harvest (Hartl et al. 1991, Hundertmark et al. 1998, Harris et al. 2002, Coltman et al. 2002, Hartl et al. 2003). Long-term patterns in selective hunting hold the potential to alter population density, sex ratio and age distribution of ungulates (Ginsberg \& Millner-Gulland 1994, Solberg et al. 2000).

Changes in the genetic underpinnings of physical characteristics can be quantified and evaluated (Kurt \& Kumarasinghe 1998, Clutton-Brock et al. 1997) where resources are not limiting antler growth; such data would provide information needed for the sound management of moose. Our results also indicate that antler size can be markedly influenced by other factors in addition to genetics. Indeed, genes coding for characteristics (large size) of antlers selected by hunters are less likely to be expressed under conditions of high population density in relation to $\mathrm{K}$ and, accordingly, the influence of harvest on genetics would be reduced under those circumstances (McCullough 1979). Clearly, more genetic data are needed to test these hypotheses.

Acknowledgements - support for this research was provided by the Federal Aid in Wildlife Restoration to the Alaska Department of Fish and Game (ADF\&G) and the Department of Biological Sciences at Idaho State University. Maps were obtained through the Alaska State Geospatial Data Clearinghouse website (http://agdc.usgs.gov/) and the Division of Wildlife Conservation, ADF\&G. We also thank the Interdisciplinary Graduate Education and Research Training Program (IGERT) of the National Science Foundation, which funded part of this research.

\section{References}

Albert, D.M., Bowyer, R.T. \& Miller, S.D. 2001: Effort and success of brown bear hunters in Alaska. - Wildlife Society Bulletin 29: 501-508.

Asleson, M.A., Hellgren, E.C. \& Varner, L.W. 1996: Nitrogen requirements for antler growth and maintenance in white-tailed deer. - Journal of Wildlife Management 60: 744-752.

Asleson, M.A., Hellgren, E.C. \& Varner, L.W. 1997: Effects of seasonal protein restriction on antlerogenesis and body mass in adult male white-tailed deer. - Journal of Wildlife Management 61: 1098-1107.
Ballard, W.B., Whitman, J.S. \& Reed, D.J. 1991: Population dynamics of moose in southcentral Alaska. - Wildlife Monographs 114: 1-49.

Barboza, P.S. \& Bowyer, R.T. 2000: Sexual segregation in dimorphic deer: a new gastrocentric hypothesis. - Journal of Mammalogy 81: 473-489.

Bender, L.C., Carlson, E., Schmitt, S.M. \& Haufler, J.B. 2003: Body mass and antler development patterns of Rocky Mountain elk (Cervus elaphus nelsoni) in Michigan. - American Midland Naturalist 50: 169-180.

Berger, J. 2005: Hunting by carnivores and humans: does functional redundancy occur and does it matter? - In: Ray, J.C., Redford, K.H., Steneck, R.S. \& Berger, J. (Eds.); Large carnivores and the conservation of biodiversity. Island Press, Washington, D.C., pp. 315-341.

Bleich, V.C., Bowyer, R.T. \& Wehausen, J.D. 1997: Sexual segregation in mountain sheep: resources or predation? - Wildlife Monographs 134: 1-50.

Bowyer, R.T. 1984: Sexual segregation in southern mule deer. - Journal of Mammalogy 65: 410-417.

Bowyer, R.T. 1986: Antler characteristics as related to social status of male southern mule deer. - Southwestern Naturalist 31: 289-298.

Bowyer, R.T. 2004: Sexual segregation in ruminants: definitions, hypotheses, and implications for conservation and management. - Journal of Mammalogy 85: 1039-1052.

Bowyer, R.T., Nicholson, M.C., Molvar, E.M. \& Faro, J.B. 1999: Moose on Kalgin Island: are density-dependent processes related to harvest? - Alces 35: 7389.

Bowyer, R.T., Pierce, B.M., Duffy, L.K. \& Haggstrom, D.A. 2001a: Sexual segregation in moose: effects of habitat manipulation. - Alces 37: 109-122.

Bowyer, R.T., Stewart, K.M., Kie, J.G. \& Gasaway, W.C. 2001b: Fluctuating asymmetry in antlers of Alaskan moose: size matters. - Journal of Mammalogy 82: 814-824.

Bowyer, R.T., Stewart, K.M., Pierce, B.M., Hundertmark, K.J. \& Gasaway, W.C. 2002a: Geographical variation in antler morphology of Alaskan moose: putative effects of habitat and genetics. - Alces 38: 155-165.

Bowyer, R.T., Stewart, K.M., Wolfe, S.A., Blundell, G.M., Lehmkuhl, K.L., Joy, P.J., McDonough, T.J. \& Kie, J.G. 2002b: Assessing sexual segregation in deer. - Journal of Wildlife Management 66: 536-544.

Bowyer, R.T., Van Ballenberghe, V. \& Kie, J.G. 1998: Timing and synchrony of parturition in Alaskan moose: long-term versus proximal effects of climate. - Journal of Mammalogy 79: 1332-1344.

Bowyer, R.T., Van Ballenberghe, V. \& Kie, J.G. 2003: Moose (Alces alces). - In: Feldhamer, G.A., Thompson, B.C. \& Chapman, J.A. (Eds.); Wild mammals of North America: biology, management, and conserva- 
tion, 2nd edition. The Johns Hopkins University Press, Baltimore, Maryland, pp. 931-964.

Brown, R.D. 1990: Nutrition and antler development. - In: Bubenik, G.A. \& Bubenik, A.B. (Eds.); Horns, pronghorns, and antlers. Springer-Verlag, New York, USA, pp. 426-441.

Bubenik, A.B. 1998: Evolution, taxonomy, and morphophysiology. - In: Franzmann, A.W. \& Schwartz, C.C. (Eds.); Ecology and management of the North American moose. Smithsonian Institution Press, Washington D.C., USA, pp. 77-123.

Clutton-Brock, T.H. 1982: The functions of antlers. - Behaviour 79: 108-125.

Clutton-Brock, T.H., Wilson, K. \& Stevenson, I.R. 1997: Density-dependent selection on horn phenotype in Soay sheep. - Philosophical Transactions of the Royal Society B 352: 839-850.

Coltman, D.W., Festa-Bianchet, M., Jorgenson, J.T. \& Strobeck, C. 2002: Age-dependent sexual selection in bighorn rams. - Proceedings of the Royal Society of London B 269: 165-172.

Coltman, D.W., O’Donoghue, P., Jorgenson, J.T., Hogg, J.T., Strobeck, C. \& Festa-Bianchet, M. 2003: Undesirable evolutionary consequences of trophy-hunting. - Nature 426: 655-658.

Cooper, A.B., Pinheiro, J.C., Unsworth, J.W. \& Hilborn, R. 2002: Predicting hunter success rates from elk and hunter abundance, season structure, and habitat. - Wildlife Society Bulletin 30: 1068-1077.

Crête, M., Taylor, R.J. \& Jordan, P.A. 1981: Optimization of moose harvest in Quebec. - Journal of Wildlife Management 45: 598-611.

Ericsson, G., Boman, M. \& Mattsson, L. 2000: Selective versus random moose harvesting: does it pay to be a prudent predator? - Journal of Bioeconomics 2: 117132.

Ferguson, S.H., Bisset, A.R. \& Messier, F. 2000: The influences of density on growth and reproduction in moose Alces alces. - Wildlife Biology 6: 31-39.

Festa-Bianchet, M., Coltman, D.W., Turelli, L. \& Jorgenson, J.T. 2004: Relative allocation to horn and body growth in bighorn rams varies with resource availability. - Behavioral Ecology 15: 305-312.

Fleming, M.D., Chapin III, F.S., Cramer, W., Hufford, G.L. \& Serreze, M.C. 2000: Geographic patterns and dynamics of Alaskan climate interpolated from a sparse station record. - Global Change Biology 6: 4958.

French, C.E., McEwen, L.C., Magruder, N.D., Ingram, R.H. \& Swift, R.W. 1965: Nutrient requirements for growth and antler development in the white-tailed deer. - Journal of Wildlife Management 20: 221-232.

Frey, S.N., Conover, M.R., Borgo, J.S. \& Messmer, T.A. 2003: Factors influencing pheasant hunter harvest and satisfaction. - Human Dimensions in Wildlife 8: $277-286$.
Fulton, D.C. \& Hundertmark, K. 2004: Assessing the effects of a selective harvest system on moose hunters' behaviors, beliefs, and satisfaction. - Human Dimensions in Wildlife 9: 1-16.

Gasaway, W.C., Boertje, R.D., Grangaard, D.V., Kelleyhouse, D.G., Stephenson, R.O. \& Larsen, D.G. 1992: The role of predation in limiting moose at low densities in Alaska and Yukon and implications for conservation. - Wildlife Monographs 120: 1-50.

Gasaway, W.C., Preston, D.J., Reed, D.J. \& Roby, D.D. 1987: Comparative antler morphology and size of North American moose. - Swedish Wildlife Research Supplement 1: 311-325.

Gasaway, W.C., Stephenson, R.O., Davis, J.L., Shepard, P.E.K. \& Burris, O.E. 1983: Interrelationships of wolves, prey, and man in interior Alaska. - Wildlife Monographs 84: 1-XX.

Geist, V. 1966: The evolution of horn-like organs. - Behaviour 27: 175-214.

Ginsberg, J.R. \& Millner-Gulland, E.J. 1994: Sex-bias harvesting and population dynamics in ungulates: implications for conservation and sustainable use. - Conservation Biology 8: 157-166.

Gross, R. 1983: Deer antlers: regeneration, function, and evolution. - Academic Press, New York, USA, $316 \mathrm{pp}$.

Harris, R.B., Wall, W.A. \& Allendorf, F.W. 2002: Genetic consequences of hunting: what do we know and what should we do? - Wildlife Society Bulletin 30: 634-643.

Hartl, G.B., Klein, F., Willing, R., Apollonio, M. \& Lang, G. 1995: Allozymes and the genetics of antler development in red deer (Cervus elaphus). - Journal of Zoology (London) 237: 83-100.

Hartl, G.B., Lang, G., Klein, F. \& Willing, R. 1991: Relationships between allozymes, heterozygosity and morphological characteristics in red deer (Cervus elaphus), and the influence of selective hunting on allele frequency distributions. - Heredity 66: 343-350.

Hartl, G.B., Zachos, F. \& Nadlinger, K. 2003: Genetic diversity in European red deer (Cervus elaphus L.): anthropogenic influences on natural populations. Comptes Rendus Biologies 326: S37-S42.

Heberlein, T.A. \& Kuentzel, W.F. 2002: Too many hunters or not enough deer? Human and biological determinants of hunter satisfaction and quality. - Human Dimensions in Wildlife 7: 229-250.

Hendee, J.C. 1974: A multiple-satisfaction approach to game management. - Wildlife Society Bulletin 2: 104113.

Hirth, D.H. 1977: Social behavior of white-tailed deer in relation to habitat. - Wildlife Monographs 53: 1-55.

Hundertmark, K.J., Thelen, T.H. \& Bowyer, R.T. 1998: Effects of population density and selective harvest on antler phenotype in simulated moose populations. - Alces 34: 375-383. 
Jenks, J.A., Smith, W.P. \& DePerno, C.S. 2002: Maximum sustained yield harvest versus trophy management. - Journal of Wildlife Management 66: 528535.

Johnston, K., Ver Hoef, J.M., Krivoruchko, K. \& Lucus, N. 2001: Using ArcGIS Geostatistical Analyst. - ESRI Press, Redlands, California.

Jorgenson, J.T., Festa-Bianchet, M. \& Wishart, W.D. 1998: Effects of population density on horn development in bighorn rams. - Journal of Wildlife Management 62: 1011-1020.

Keech, M.A., Boertje, R.D., Bowyer, R.T. \& Dale, B.W. 1999: Effects of birth weight on growth of young moose: do low-weight neonates compensate? - Alces 35: 51-57.

Keech, M.A., Bowyer, R.T., Ver Hoef, J.M., Boertje, R.D., Dale, B.W. \& Stephenson, T.R. 2000: Life-history consequences of maternal condition in Alaskan moose. - Journal of Wildlife Management 64: 450462.

Kie, J.G. \& Bowyer, R.T. 1999: Sexual segregation in white-tailed deer: density-dependent changes in use of space, habitat selection, and dietary niche. - Journal of Mammalogy 80: 1004-1020.

Kie, J.G., Bowyer, R.T. \& Stewart, K.M. 2003: Ungulates in western forests: habitat requirements, population dynamics, and ecosystem processes. - In: Zabel, C.J. \& Anthony, R.G. (Eds.); Mammal community dynamics: management and conservation in the coniferous forests of western North America. Cambridge University Press, New York, USA, pp. 296340.

Kurt, F. \& Kumarasinghe, J.C. 1998: Remarks on body growth and phenotypes in Asian elephants Elaphas maximus. - Acta Theriologica, Supplement 5: 135153.

Laurian, C., Ouellet, J.P., Courtois, R., Brenton, L. \& St-Onge, S. 2000: Effects of intensive harvesting on moose reproduction. - Journal of Applied Ecology 37: 515-531.

Loison, A., Gaillard, J-M., Pélabon, C. \& Yoccoz, N.G. 1999: What factors shape sexual size dimorphism in ungulates? - Evolutionary Ecology Research 1: 611633.

Maier, J.A.K., Ver Hoef, J., McGuire, A.D., Bowyer, R.T., Saperstein, L. \& Maier, H.A. 2005: Distribution and density of moose in relation to landscape characteristics: effects of scale. - Canadian Journal of Forest Research 35: 2233-2243.

Malo, A.F., Roldan, E.R.S., Garde, J., Soler, A.J. \& Gomendio, M. 2005: Antlers honestly advertise sperm production and quality. - Proceedings of the Royal Society B 272: 149-157.

McCullough, D.R. 1979: The George Reserve deer herd: population ecology of a K-selected species. - University of Michigan Press, Ann Arbor, Michigan, $271 \mathrm{pp}$.
McCullough, D.R. 1982: Antler characteristics of George Reserve white-tailed deer. - Journal of Wildlife Management 46: 821-826.

McCullough, D.R. 2001: Male harvest in relation to female removals in black-tailed deer. - Journal of Wildlife Management 65: 46-58.

Miquelle, D.G. 1990: Why don't bull moose eat during the rut? - Behavioral Ecology and Sociobiology 27: 145-151.

Miquelle, D.G., Peek, J.M. \& Van Ballenberghe, V. 1992: Sexual segregation in Alaskan moose. - Wildlife Monographs 122: 1-57.

Moen, R. \& Pastor, J. 1998: A model to predict nutritional requirements for antler growth in moose. - Alces 34: 59-74.

Molvar, E.M. \& Bowyer, R.T. 1994: Costs and benefits of group living in a recently social ungulate: the Alaskan moose. - Journal of Mammalogy 75: 621-630.

Molvar, E.M., Bowyer, R.T. \& Van Ballenberghe, V. 1993: Moose herbivory, browse quality, and nutrient cycling in an Alaskan treeline community. - Oecologia 94: 472-479.

Mysterud, A., Coulson, T. \& Stenseth, N.C. 2002: The role of males in the dynamics of ungulate populations. - Journal of Animal Ecology 71: 907-915.

Mysterud, A., Holand, O., Roed, K.H., Gjoestein, H., Kumpula, J. \& Nieminen, M. 2003: Effects of age, density and sex ratio on reproductive effort in male reindeer (Rangifer tarandus). - Journal of Zoology (London) 261: 341-344.

O’Neil, K.P., Kasischke, E.S. \& Richter, D.D. 2002: Environmental controls on soil $\mathrm{CO} 2$ flux following fire in black spruce, white spruce, and aspen stands of interior Alaska. - Canadian Journal of Forest Research 32: 1525-1541.

Pélabon, C. 1997: Is weight at birth a good predictor of weight in winter for fallow deer? - Journal of Mammalogy 78: 48-54.

Ralls, K. 1977: Sexual dimorphism in mammals: avain models and unanswered questions. - American Naturalist 122: 917-938.

Rousseeuw, P.J. \& Van Zomeren, B.C. 1990: Unmasking multivariate outliers and leverage points. - Journal of the American Statistical Association 85: 633-639.

Sand, H., Cederlund, G. \& Danell, K. 1995: Geographical and latitudinal variation in growth-patterns and adult body-size of Swedish moose (Alces alces). - Oecologia 102: 433-442.

SAS Institute Inc. 1999: SAS/STAT guide for personal computers. Version 8. - SAS Institute Inc., Cary, North Carolina.

Sæther, B-E. \& Haagenrud, H. 1983: Life history of moose (Alces alces): fecundity rates in relation to age and carcass weight. - Journal of Mammalogy 64: 226-232.

Sæther, B-E. \& Haagenrud, H. 1985: Geographical variation in the antlers of Norwegian moose in relation 
to age and size. - Journal of Wildlife Management 49: 983-986.

Sæther, B-E., Engen, S. \& Solberg, E.J. 2001: Optimal harvest of age-structured populations of moose Alces alces in a fluctuating environment. - Wildlife Biology 7: 171-179.

Sæther, B-E., Solberg, E.J. \& Heim, M. 2003: Effects of altering sex ratio structure on the demography of an isolated moose population. - Journal of Wildlife Management 67: 455-466.

Sæther, B-E., Solberg, E.J., Heim, M., Stacy, J.E., Jakobsen, K.S. \& Olstad, R. 2004: Offspring sex ratio in moose Alces alces in relation to paternal age: an experiment. - Wildlife Biology 10: 51-57.

Schmidt, J.I., Ver Hoef, J.M., Maier, J.A.K. \& Bowyer, R.T. 2005: Catch per unit effort for moose: a new approach using Weibull regression. - Journal of Wildlife Management 69: 1112-1124.

Schmidt, K.T., Stien, A., Albon, S.D. \& Guinness, F.E. 2001: Antler length of yearling red deer is determined by population density, weather and early life-history. - Oecologia 27: 191-197.

Schwartz, C.C., Hundertmark, K.J. \& Becker, E.F. 1994: Growth of moose calves conceived during the first versus second estrus. - Alces 30: 91-100.

Schwartz, C.C., Hundertmark, K.J. \& Spraker, T.H. 1992: An evaluation of selective bull harvest on the Kenai Peninsula, Alaska. - Alces 28: 1-13.

Schultz, S.R. \& Johnson, M.K. 1995: Effects of birth date and body mass at birth on adult body mass of male white-tailed deer. - Journal of Mammalogy 76 : 575-597.

Singer, F.J. \& Zeigenfuss, L.C. 2002: Influence of trophy hunting and horn size on mating behavior and survivorship of mountain sheep. - Journal of Mammalogy 83: 682-698.

Snepenger, D.J. \& Bowyer, R.T. 1990: Differences among nonresident tourists making consumptive and non consumptive uses of Alaskan wildlife. - Arctic 43: 262-266.

Solberg, E.J., Loison, A., Sæther, B-E. \& Strand, O. 2000: Age-specific harvest mortality in a Norwegian moose Alces alces population. - Wildlife Biology 6: 41-52.

Solberg, E.J. \& Sæther, B-E. 1993: Fluctuating asymmetry in the antlers of moose (Alces alces) - does it signal male quality? - Proceedings of the Royal Society of London B 254: 251-255.

Solberg, E.J. \& Sæther, B-E. 1994: Male traits as lifehistory variables: annual variation in body mass and antler size in moose (Alces alces). - Journal of Mammalogy 75: 1069-1079.

Solberg, E.J., Sæther, B-E., Strand, O. \& Loison, A. 1999: Dynamics of a harvested moose population in a variable environment. - Journal of Animal Ecology 68: 186-204.
Spaeth, D.F., Hundertmark, K.J., Bowyer, R.T., Barboza, P.S., Stephenson, T.R. \& Peterson, R.O. 2001: Incisor arcades of Alaskan moose: is dimorphism related to sexual segregation? - Alces 37: 217-226.

Stewart, K.M., Bowyer, R.T., Dick, B.L., Johnson, B.K. \& Kie, J.G. 2005: Density-dependent effects on physical condition and reproduction in North American elk: an experimental test. - Oecologia 143: 85-93.

Stewart, K.M., Bowyer, R.T., Kie, J.G. \& Gasaway, W.C. 2000: Antler size relative to body mass in moose: tradeoffs associated with reproduction. - Alces 36: 77-83.

Stewart, R.R. 1985: Game harvest management. A sexand age-selective harvest strategy for moose management in Saskatchewan. - In: Beasom, S.L. \& Robertson, S.S. (Eds.); Proceedings of the 3rd International Symposium of the Ceasar Kleberg Wildlife Research Institute. Texas A\&I University, Kingsville, Texas, pp. 229-238.

Strickland, B.K. \& Demarais, S. 2000: Age and regional differences in antlers and mass of white-tailed deer. - Journal of Wildlife Management 64: 903-911.

Strickland, B.K., Demarais, S., Castle, L.E. \& Lipe, J.W. 2001: Effects of selective-harvest strategies on white-tailed deer antler size. - Wildlife Society Bulletin 29: 509-520.

Thelen, T.H. 1991: Effects of harvest on antlers of simulated populations of elk. - Journal of Wildlife Management 55: 243-249.

Timmermann, H.R. \& Buss, M.E. 1998: Population and harvest management. - In: Franzmann, A.W. \& Schwartz, C.C. (Eds.); Ecology and management of the North American moose. Smithsonian Institution Press. Washington, D.C., pp. 559-615.

Van Ballenberghe, V. 1983: Growth and development of moose antlers in Alaska. - In: Brown, R.D. (Ed.); Antler development in Cervidae. Caesar Kleberg Wildlife Research Institute, Kingsville, Texas, pp. 37-48.

Van Ballenberghe, V. \& Miquelle, D.G. 1996: Rutting behavior of moose in central Alaska. - Alces 32: 109130.

Ver Hoef, J.M. 2001: Predicting finite populations from spatially correlated data. - In: Proceedings of the section on statistics and the environment of the American Statistical Association 2000, pp. 93-98.

Ver Hoef, J.M. 2002: Sampling and geostatistics for spatial data. - Écoscience 9: 152-161.

Weckerly, F.W. 1998: Sexual-size dimorphism: influence of mass and mating systems in the most dimorphic mammals. - Journal of Mammalogy 79: 33-52.

Weixelman, D.A., Bowyer, R.T. \& Van Ballenberghe, V. 1998: Diet selection by Alaskan moose during winter: effects of fire and forest succession. - Alces 34: 213-238.

Whittle, C.L., Bowyer, R.T., Clausen, T.P. \& Duffy, L.K. 2000: Putative pheromones in urine of rutting 
male moose (Alces alces): evolution of honest advertisement? - Journal of Chemical Ecology 26: 27472762.

Yarie, J. \& Billings, S. 2002: Carbon balance of the taiga forest within Alaska: present and future. - Canadian Journal of Forest Research 32: 757-767.
Yoccoz, N.G., Mysterud, A., Langvatn, R. \& Stenseth, N.C. 2002: Age and density-dependent reproductive effort in male red deer. - Proceedings of the Royal Society of London B 269: 1523-1529.

Zar, J.H. 1999: Biostatistical analysis, 4th edition. - Prentice-Hall, Upper Saddle River, New Jersey, 663 pp. 